\title{
Can Farmers Receive Their Expected Seasonal Tomato Price in Ghana? A Probit Regression Analysis
}

\author{
Caleb Attoh ${ }^{1}$, Edward Martey ${ }^{2}$, G.T. M. Kwadzo ${ }^{3}$, Prince M. Etwire ${ }^{2} \&$ Alexander N. Wiredu ${ }^{2,4}$ \\ ${ }^{1}$ Audit Service, Cape-Coast, Ghana \\ ${ }^{2}$ CSIR-Savanna Agricultural Research Institute, Ghana \\ ${ }^{3}$ Department of Agricultural Economics and Agribusiness, University of Ghana, Legon, Ghana \\ ${ }^{4}$ Rural Development Theory and Policy, Institute of Agricultural Economics and Social Sciences in Tropics and \\ Subtropics, University of Hohenheim, Stuttgart, Germany
}

Correspondence: Edward Martey, P.O. Box TL 52, Tamale, Ghana. Tel: 233-242-344-450. E-mail: eddiemartey@gmail.com

Received: October 25, 2013 Accepted: February 7, 2014 Online Published: February 10, 2014

doi:10.5539/sar.v3n2p16 URL: http://dx.doi.org/10.5539/sar.v3n2p16

\begin{abstract}
Tomato price is an important indicator for farmers to continue producing the crop in Ghana. There are sometimes alleged reports that farmers tend to commit suicide when they are unable to meet their expected tomato price and thereby unable to recover their cost of production. However, data available indicate that the domestic production of fresh tomato is on the decline. The paper therefore, assesses the factors that affect whether or not farmers can receive their expected tomato price. A multistaged sample survey of 215 farmers across three regions was subjected to the binomial probit model. Results indicate that for farmers to receive their expected price, they have to adapt to produce the crop in the drier seasons, where tomato shortage can be observed. Farmer education and experience are also important factors that are likely to help farmers receive their expected tomato price. The studytherefore recommends the promotion of strategies that are cost reducing especially in the dry season and also to improve access to critical production techniques.
\end{abstract}

Keywords: seasonal, expected price, tomato, cultivation, binomial probit model, Ghana

\section{Introduction}

\subsection{Background and Problem Statement}

The Ghanaian agricultural sector plays an important role in economic development. It contributes significantly to food security, poverty reduction and GDP growth in the country. The sector is the largest single employer of labour in the Ghanaian economy and is dominated by many rural smallholder farms and agricultural enterprises (Aryeetey \& Nyanteng, 2006; Kolavalli et al., 2011). The crops sub-sector is a major component in the agricultural sector (MoFA, 2010). This sub-sector includes tomato production which is one of the essential farming and import activities in the country. Tomato (Lycopersicon spp.) is an essential vegetable, a vital ingredient in the diet of Ghanaians and it is easy to grow. Tomato is used in many dishes in Ghana in its raw or processed form. It grows well in the tropics, which also makes it highly perishable. When harvested ripped, they tend to rot within a few days and create problems for farmers and marketers in times of seasonal glut when they are unable to sell immediately. A useful substitute of this perishable fruit is in its preserved form as puree or paste. Processing appears to be the main remedy to the perennial gluts in the tomato producing sector (Robinson \& Kolavalli, 2010).

Tomato production as an agricultural business has great potential for growth and employment generation (Robinson \& Kolavalli, 2010). Although tomato requires a relatively cool, dry climate for high yield and quality, it can adapt to a wide range of climatic conditions from temperate to hot and humid tropical. The optimum temperature for most varieties lies between $21{ }^{\circ} \mathrm{C}$ and $24^{\circ} \mathrm{C}$. The plants can survive a range of temperature, but the plant tissues are damaged below $10^{\circ} \mathrm{C}$ and above $38^{\circ} \mathrm{C}$ (Naika et al., 2005). The possibilities of increasing its domestic production will not only involve transforming some institutions such as the land tenure systems, input and credit but also the pricing policies and strategies farmers adopt (Donkoh et al., 2013). The production of tomato is characterized by seasonal patterns and prices vary substantially even within a week (Ihle \& 
Amikuzuno, 2010). Its seasonality creates periods of abundance and scarcity reflecting in market prices.

Tomato production in Ghana follows the difference in rainfall patterns and access to water. Different regions therefore, participate in tomato production at different times of the year. The use of washed seeds is still done by Ghanaian farmers who produce without targeting any buyer and deliver to the open market (Clottey et al., 2009). This situation increases transaction cost and exposes farmers to high market risk. Fresh tomato prices are affected by seasonality than by quality. With the different varieties of tomato produced in Ghana and that from Burkina Faso, tomato quality deteriorates as a result of inappropriate postharvest practices, such as lack of appropriate storage, cooking facilities and unsuitable commercial containers (Horna et al., 2007). All these can possibly affect the tomato price received by farmers. However, figures indicate that there is a declining trend in domestic production of fresh tomato (FAOSTAT, 2011; Attoh, 2011). On the other hand, tomato price is an important indicator for farmers to continue producing by influencing their profits. The main objective of this research therefore, is to identify factors that influence the seasonal expected tomato price negotiated and received by farmers.

\section{Method}

\subsection{Study Area}

The research uses three (3) main tomato producing districts in three (3) regions of Ghana namely Brong Ahafo, Upper East and Ashanti Regions. The three districts are described below:

Wenchi District: This district, now a municipality can be found in the western part of the Brong Ahafo Region. It is located northwest to Sunyani, the regional capital. Major economic activities in the municipality are agriculture and forestry. Most farmers acquire land through inheritance or work on family lands. The major crops grown are maize, tomatoes, yam, plantain and cassava. Hired labour is the major source of labour (ghanadistricts.com, 2011). Communities involved in tomato production in the district are Nkonsia, Awisa and Asubinja.

Offinso North District: The district can be found in the North-Western part of the Ashanti region bordered by the Brong Ahafo Region in the north and west. The district experiences semi-equatorial conventional climate. Soils are suitable for the cultivation of crops such as cassava, yam, maize and vegetables (for example tomatoes). Agriculture is the dominant economic activity in the district (ghanadistricts.com, 2011). Communities involved in tomato production in the district includes Akomadan and Afrancho.

Kasena Nankana East District: This district falls within the savannah vegetation belt and rainfall is modest with only one rainy season. This allow for the cultivation of legumes, cereals and vegetable for own consumption and for the market only in a season without the use of irrigation (ghanadistricts.com, 2011). Communities involved in tomato production in the district includes Tono, Doba, Mingu, Pungu Bavugenia and Nyangua.

\subsection{Sampling Technique and Data Collection}

The study used a multistage sampling technique to select the farmers. It started with a purposive selection of three regions namely Upper East, Brong Ahafo and Ashanti Regions. These regions are well known as areas for commercial tomato production in Ghana. The next stage involved a purposive selection of one district from each region namely Kasena Nankana East District in the Upper East Region, Wenchi District in the Brong Ahafo Region and Offinso North District in the Ashanti Region with the aid of the officials at the Ministry of Food and Agriculture (MoFA). Finally, farmers were selected randomly from the list of tomato producing households in each of the identified districts. In summary, 159 farmers (60 respondents from Akomadan, 52 from Kasena Nankana East and 47 from Wenchi) were sampled and interviewed.

Data for the research was collected based on the number of times each farmer was engaged in producing tomato during the 2010/2011 production year (i.e. seasons of production). The questions were then repeated for the number of seasons identified for each farmer. There were three seasons categorized, representing seasons in which farmers produced tomato. Primary data captured include socio-economic, demographic and institutional factors. Secondary data source was also used to augment the primary data. In all, 215 data points on seasonal production basis were collected and used for the analysis in the research.

\subsection{Method of Analysis}

\subsubsection{Binary Probit Model Analysis}

Tomato harvesting can span for a few weeks before it is over. Therefore, farmers either sold their harvest immediately or waited for a fewdays when they think the price might be better. For a farmer to negotiate and 
choose to receive any price for the $52 \mathrm{~kg}$ crate of tomato or not can be viewed as a discrete choice. Discrete choice models like probit and logit model can therefore, be used for this analysis. However, the probit model specification has an advantage over the logit model specification for small samples (less than 1000) (Johannes et al., 2010). The present study therefore, used a Binomial Probit Model to examine determinants of whether or not farmers can receive their expected tomato price. It is assumed that whether farmers receive their expected price or not is closely related to the way farmers use their technical information to negotiate for a better tomato price. They decide on how much to sell knowing that the harvest season will span a few days (more than one day). The decision maker (farmer) is assumed to maximize expected utitiy (expected profit) by negotiating a possibly higher price subject to some constraints.

The structure of the model is therefore, represented as:

$$
\begin{gathered}
Y_{i}=\operatorname{lif}\left(X_{i}, \beta_{i}\right)+e \geq 0 \text { and } Y_{i}=0 i f\left(X_{i}, \beta_{i}\right)+e<0 \\
Y_{i}=\beta_{0}+X_{i}^{\prime} \beta_{i}+e_{i}
\end{gathered}
$$

Where $Y_{i}$ is the discrete acceptance variable, $\beta_{i}$ is the vector of parameters, $X_{i}$ is the vector of explanatory variables, is $\beta_{0}$ is the constant term and $e_{i}$ is the error term.

Farmers were asked to provide their expected price range for their tomato for the different season identified. Where the weighted average price per season received by the farmer for their $52 \mathrm{~kg}$ crate of tomato for a particular season falls within the expected price range the farmer mentioned, the farmer is then assumed to have negotiated his expected price for the particular season. The dependent variable is such that a farmer who receives his expected price in each season in the 2010/2011 tomato production year is given a value of one and if not, a value of zero. The model estimates give the directional effect whiles the marginal effect of changes in an explanatory variable on whether or not the farmer can receive his expected tomato price is given below (Fufa \& Hassan, 2006):

$$
\frac{\partial E\left[\frac{Y_{i}}{X_{i}}\right]}{\partial X_{i}}=\beta_{i} \theta\left(\beta_{i}^{\prime} X_{i}\right)
$$

Where $\theta$ is the standard normal density function.

\subsection{Description of Explanatory Variables}

The independent explanatory variables used in the model of study include farmer education and experience, whether the farmer has off-farm income, use of seeds form formal sources, access to credit, being a member of a farmer association, farm size for tomato cultivation and tomato price. Output price serves as an incentive for farmers to decide the marketing channel to use (Martey et al., 2012). The amount received by a farmer is an indication of their negotiating ability. The weighted average price of tomato is therefore, used as a proxy for the negotiating ability of farmers. If farmers think they can negotiate a good and higher price, then they will expect a higher price for their produce. Farmer experience is hypothesized to influence farmer expectation of tomato price. Older and more experienced farmers have the advantage of dealing with most buyers and are able to use the information for their benefit. They have better contacts possibly at lower cost. Farmer experience helps them gain acquaintance with existing systems and information (Fufa \& Hassan, 2006) which they are expected to use efficiently in order to gain their expected commodity price. Also, farmer education is expected to influence farmer expectation of the commodity price. Highly educated farmers have a negotiative urge and can better articulate their position for a higher tomato price. Farmer education improves the allocative ability of decision makers by enabling them think critically and use information source efficiently (Fufa \& Hassan, 2006; Johannes et al., 2010).

A farmer with off-farm income is hypothesized to affect farmer expectation of commodity price. It would reduce their perception of risk (Shapiro \& Brorsen, 1988; Chebil et al., 2009) against a lower commodity price. The expectation therefore, of such a farmer could be towards a lower commodity price. However, the nature of a Ghanaian farmer is to expect a good and higher commodity price in order to achieve their expected profit level. A farmer who uses seeds from formal sources is expected to influence his expected commodity price. These seeds are expected to be the improved varieties that have market value and therefore farmers have a positive expectation of commodity price for using such seeds. Having access to credit is an important indication for a farmer to expect a higher commodity price, in order to recover the cost of using credit. Access to credit is 
therefore hypothesized to positively influence farmer's expectation of tomato price. Being a member of a farmer association is positively associated with farmer's expectation of commodity price. This is because these farmers have access to information and training derived from collective investments (Chebil et al., 2009) to benefit them when negotiating the commodity price. Finally, farm size is expected to give an indication of a farmer's expectation of tomato price. If a farmer expects a higher tomato price, he or she could increase farm land to tomato to take advantage of higher profits. On the order hand, if a farmer expects a lower tomato price, he or she cultivates a small farm land to tomato and a bigger farmland to other crops which he or she expects a higher commodity price. Two interaction terms were also used. Seasonality (used as a dummy) is interacted with use of any type of irrigation technology and farmer experience was interacted with the weighted average price of tomato.

\section{Results and Discussion}

\subsection{Descriptive Results}

Seasonality is characterized into three, season one, season two and season three which represents harvesting periods between April to July, August to November and December to March respectively. Season one and season two can be observed as the major and minor rainy season for Akomadan and Wenchi. Season two can be observed as the modest single rainy season for Kasena Nankana East but season three is the dry season for all locations. Relatively, from the sample, the main tomato producing season for Akomadan, Wenchi and Kasena Nankana East are season one, season two and season three respectively. These recorded a higher percentage of cultivation by tomato farmers in these seasons during the 2010/2011 production year. This is shown in appendix two. Farmers consider pricing as a very important part of the production system. This depends on their ability to negotiate mostly with market women from across the country. Most farmers sell their produce on their farms. This applies in all districts, however, only Kasena Nankana East District had a few farmers sending some of their produce to sell in a nearby market. Tomato output price, overall, varied across locations.

The average price farmers received for the sample is 74.09 Ghana cedis per $52 \mathrm{~kg}$ crate of tomato. Kasena Nankana East District farmers received the highest average price of 99.90 Ghana cedis per $52 \mathrm{~kg}$ crate of tomato (an average of 33.90 Ghana cedis in season two and 101.40 Ghana cedis for season three). This is followed by Akomadan farmers who received an average price of 85.30 Ghana cedis per $52 \mathrm{~kg}$ crate of tomato (an average of 101.11 Ghana cedis in season one, 60.10 Ghana cedis in season two and 82.14 Ghana cedis for season three). Wenchi farmers then followed with an average price of 41.5 Ghana cedis per $52 \mathrm{~kg}$ crate of tomato (an average of 39.45 Ghana cedis in season one, 43.19 Ghana cedis in season two and 43.11 Ghana cedis for season three). Tomato prices are highest in season three comparable with a higher majority of farmers receiving higher prices as shown by their smaller standard deviation. This is represented in appendix 3. Out of the 215 responses or data points generated in the sample, 32.56 percent are from Wenchi District in the Brong Ahafo Region (45.71 percent for season one, 48.57 percent for season two and 5.71 percent for season three), 41.86 percent are from Akomadan in the Ashanti Region (51.09 percent for season one, 31.52 percent for season two and 17.39 percent for season three) and 24.65 percent are from Kasena Nankana East in the Upper East Region (none for season one, 1.89 percent for season two and 98.11 percent for season three).

\subsection{Probit Estimates for the Expected Tomato Price Received}

The binomial probit model was used to estimate coefficients of the determinants of whether or not farmers can receive their expected tomato price in Ghana. The model estimates are shown in appendix 4. The Stata 11 software was used to estimate parameters and their marginal effect. The model has explanatory power with a Pseudo R squared of 49.72 which indicate that 50 percent of the variation in the dependent variable is explained by the independent variables. It also has a wild chi squared value of 56.59 significant at a one percent confidence level. The marginal effects estimated are presented in Table 1. The empirical results of the Binomial Probit Model show that three (3) out of the nine (9) used independent variables were significant. From the results, the interaction term of seasonality and use of any irrigation technology is significant in the model. This means that as the seasons wears on and rainfall decreased towards the drier seasons, a farmer who uses any irrigation technology has a higher likelihood of receiving his/her expected tomato price he/she negotiated for. This could be due to tomato shortages experienced during the dry season in Ghana which is expected to generally increase the price of tomato. As season progressed toward the drier season, a farmer with any irrigation scheme is likely to increase his probability of receiving his/her expected tomato price by 83 percent.

Also the interaction term of farmer experience and weighted average price of tomato is significant which means that experienced farmers who can bargain for a good and higher price (have a higher negotiating ability) for their $52 \mathrm{~kg}$ crate of tomato have a higher likelihood of receiving their expected tomato price they negotiate for. This 
could be due to the fact that experienced farmers gain acquaintance with new information which they use efficiently that helps them negotiate better (Fufa \& Hassan, 2006). An experienced farmer who can negotiate a higher tomato price is likely to increase his probability of receiving his expected tomato price by 0.21 percent. Farmer education is also significant which means that educated farmers have a higher likelihood of receiving their expected tomato price they negotiate for. This is probably because they become aware of additional sources of information and are more efficient at evaluating, interpretation and negotiation (Fufa \& Hassan, 2006; Johannes et al., 2010). An additional year of education is likely to increase the probability of a farmer to receive his / her expected tomato price by 9.32 percent.

Table 1. Marginal effect of the binomial probit model

\begin{tabular}{ll}
\hline Variable & Marginal Effect \\
\hline Seasonality*Access to any irrigation technology & $0.8261^{* *}$ \\
Farmer education & $0.0932^{* *}$ \\
Farmer experience*Weighted seasonal average tomato price of a crate & $0.0021^{* * *}$ \\
\hline
\end{tabular}

Source: Regression Estimation from Survey Data (2011)

$* * * \mathrm{p}<0.01, * * \mathrm{p}<0.05$ and $* \mathrm{p}<0.10$.

\section{Conclusion}

The binomial probit model shows that, in Ghana, farmers can receive their expected tomato price. As seasons progressed towards the drier season, a farmer who uses any irrigation technology is likely to increase his chances of receiving his expected price. Also, experienced farmers who have cultivated tomato for a longer period of time and can negotiate a higher price for their tomato also have a higher likelihood of increasing their chance of receiving their expected higher price. Farmer education is also likely to influence the likelihood and chance for a farmer to gain a higher price for their $52 \mathrm{~kg}$ crate of tomato. Fundamental to improving farmers chances of receiving their expected price depends on strategies that help farmers reduce their cost of irrigation which could include cost sharing arrangements or the building of dams for collective use especially in the drier areas and seasons. It is also important to use strategies that encourage more farmers to grow tomatoes in the drier seasons which can increase income and thereby the welfare of these farmers. Farmers can be helped with credit to gain farm land close to already existing dams and also for agricultural development organisation to develop seeds that do well in drier environments and to educate farmer on possible and appropriate storage facilities.

\section{Acknowledgements}

The author acknowledge the many tomato farmers who cultivate and produce to meet the needs of the country and especially to those who took a long time to sit and answer questions that were repeated on seasonal basis. The reviewers of this paper are also appreciated for their valuable comments.

\section{Reference}

Aryeetey, E., \& Nyanteng, V. (2006). Agricultural Market Access In Ghana. ISSER Discussion Paper No. 30, ISSER, University of Ghana, Legon.

Attoh, C. (2011). Assessing the Competitiveness and Factors Affecting Farmers' Seasonal Tomato Production Decisions in Ghana. An unpublished MPhil Thesis, Department of Agricultural Economics and Agribusiness, University of Ghana, Legon.

Chebil, A., Nasr, H., \& Zaibet, L. (2009). Factors Affecting Farmers' Willingness to Adopt Salt-Tolerant Forage crops in South Eastern Tunisia. AfJare, 3(1), 19-27.

Clottey, V. A., Karbo, N., \& Gyasi, K. O. (2009). The Tomato Industry in Northern Ghana: Production Constraints and Strategies to Improve Competitiveness. African Journal of Food, Agriculture Nutrition and Development, 9(6), 1436-1451. http://dx.doi.org/10.4314/ajfand.v9i6.46265

Donkoh, S. A., Tachega, M., \& Amowine, N. (2013). Estimating Technical Efficiency of Tomato Production in Northern Ghana. American Journal of Experimental Agriculture, 3(1), 56-75.

FAOSTAT. (2011). http://faostat.fao.org/site/342/default.aspx, accessed on 15th February, 2011.

Fufa, B., \& Hassan, R. M. (2006). Determinants of fertilizer use on maize in Eastern Ethiopia: A weighted 
endogenous sampling analysis of the extent and Intensity of adoption. Agrekon, 45(1), 38-49. http://dx.doi.org/10.1080/03031853.2006.9523732

Ghanadistricts.com. (2011). ghanadistricts.com, accessed on 8th April, 2011.

Horna, D., Timpo, S., Al-Hassan, M. R., Smale, M., \& Falck-Zepeda, J. (2007). Vegetable production and pesticide use in Ghana: World GM Varieties have an Impact at the Farm Level? (pp. 473-477). AAAE Conference Proceedings.

Ihle, R., \& Amikuzuno, J. (2010). Assessing Seasonal Asymmetric Price transmission in Ghanaian Tomato markets with the Johansen Estimation Method. Georg-August-Universitat Gottingen, Discussion papers No. 53.

Johannes, T. A., Vabi, M. B., \& Malaa, D. K. (2010). Adoption of maize and cassava Production Technologies in the Forest-Savannah zone of Cameroon: Implications for Poverty Reduction. World Applied Sciences Journal, 11(2), 196-209.

Kolavalli, S., Robinson, E., Diao, X., Alpuerto, V., Folledo, R., Slavova, M., \& Asante, F. (2011). Economic Transformation in Ghana. A paper presented at the IFPRI-University of Ghana Conference (pp. 1-5). Understanding Economic Transformation in Sub-Saharan Africa.

Martey, E., Annin, K., Wiredu, A. N., \& Attoh, C. (2012). Does Access to Market Information Determine the Choice of Marketing Channel among Small holder Yam Farmers in the Brong Ahafo Region of Ghana? A Multinomial Logit Regression Analysis. Journal of Economics and Sustainable Development, 3(12), 18-28.

Ministry of Food and Agriculture. (2010). Agriculture in Ghana, Facts and Figures (2009), Statistical, Research Information Directorate (SRID), Ministry of Food and Agriculture, MoFA, Accra.

Naika, S., van Lidt de Jeude, J., de Goffau, M., Hilmi, M., \& van Dam, B. (2005). Cultivation of Tomato. Production, Processing and Marketting (pp. 1-10). Agrodok 17, Dififrafi, Wageningen, Netherlands.

Robinson, J. Z. E., \& Kolavalli, S. L. (2010). The Case of Tomato in Ghana: Institutional Support. Ghana Strategy Support Program (GSSP) Working Paper No. 22. IFPRI, Accra.

Shapiro, B. I., \& Brorsen, B. W. (1988). Factors Affecting Farmers' Hedging Decisions. North Central Journal of Agricultural Economics, 10(2), 145-153. http://dx.doi.org/10.2307/1349215 


\section{Appendices}

Appendix 1. Explanatory variables for the binomial probit model

\begin{tabular}{|c|c|c|c|}
\hline No & Variable & Measurement & $\begin{array}{l}\text { Expected } \\
\text { Sign }\end{array}$ \\
\hline 1 & Location of Farmer & $\begin{array}{l}0 \text { if Kasena Nankana East, } 1 \text { if Wenchi and } 2 \text { if } \\
\text { Akomadan Districts }\end{array}$ & $+/-$ \\
\hline 2 & Seasonality & 0 if season one, 1 if season two and 2 if season three & $+/-$ \\
\hline 3 & Farmer education & Number of years of formal education & + \\
\hline 4 & Farmer experience & Number of years in tomato farming & + \\
\hline 5 & Off farm income source & $\begin{array}{l}\text { Dummy: } 1=\text { Agric and any off-farm income activity, } \\
0=\text { only Agric }\end{array}$ & $+/-$ \\
\hline 6 & Source of Seed & $\begin{array}{l}\text { Dummy: } 1=\text { from formal sources like Agric } \\
\text { Shop/NGOs, } 0=\text { prepared by farmer/friends }\end{array}$ & + \\
\hline 7 & Farm land for tomato cultivation & Hectare & + \\
\hline 8 & $\begin{array}{l}\text { Weighted seasonal average price } \\
\text { of tomato }\end{array}$ & Ghana cedis & + \\
\hline 9 & Farmer association & $\begin{array}{l}\text { Dummy: } 1=\text { member of any farmer association, } \\
0=\text { otherwise }\end{array}$ & + \\
\hline 10 & Access to credit & Dummy: $1=$ if received credit, $0=$ otherwise & + \\
\hline \multirow[t]{2}{*}{11} & Irrigation & Dummy: $1=$ if used any irrigation system, $0=$ otherwise & + \\
\hline & Interaction terms & & \\
\hline 12 & $\begin{array}{l}\text { Seasonality and Access to any } \\
\text { irrigation technology }\end{array}$ & Seasonality*Access to any irrigation technology & $+/-$ \\
\hline 13 & $\begin{array}{l}\text { Farmer experience and Weighted } \\
\text { average price }\end{array}$ & Farmer experience $*$ Seasonal Weighted average price & + \\
\hline
\end{tabular}

Appendix 2. Location of farmers and seasonality of tomato production in the three districts

\begin{tabular}{cccc}
\hline & \multicolumn{3}{c}{ Location of Farmer (percentage) } \\
\cline { 2 - 4 } Seasonaliy(percentage) & Wenchi & Akomadan & K. Nankana East \\
& $(\mathrm{N}=70)$ & $(\mathrm{N}=92)$ & 0.00 \\
\hline Season one $(\mathrm{N}=79)$ & 45.71 & 51.09 & 1.89 \\
Season two $(\mathrm{N}=64)$ & 48.57 & 31.52 & 98.11 \\
Season three $(\mathrm{N}=72)$ & 5.71 & 17.39 & \\
\hline
\end{tabular}


Apendix 3. Summary statistics of weighted average price across locations and seasons

\begin{tabular}{cccccc}
\hline \multirow{2}{*}{ Wenchi } & & \multicolumn{4}{c}{ Seasons } \\
\cline { 3 - 5 } & Mean & Season 1 & Season 2 & Season 3 & Total \\
& Minimum & 13.45 & 43.19 & 43.11 & 41.50 \\
& Maximum & 184.30 & 14.63 & 21.02 & 13.00 \\
Akomadan & SD & 32.05 & 103.1 & 54.48 & 184.30 \\
& Mean & 101.11 & 60.10 & 19.13 & 26.90 \\
& Minimum & 9.29 & 5.00 & 82.14 & 85.30 \\
& Maximum & 269.03 & 115.74 & 13.91 & 5.00 \\
& SD & 71.00 & 28.4 & 28.80 & 269.03 \\
& Mean & 0.00 & 33.9 & 101.40 & 57.37 \\
& Minimum & 0.00 & 33.0 & 18.61 & 99.90 \\
& Maximum & 0.00 & 33.9 & 249.49 & 249.49 \\
& SD & 0.00 & 0.00 & 45.40 & 45.99 \\
\hline
\end{tabular}

Source: Author's computation from field data.

Appendix 4. Binomial probit model results for the expected tomato price received

\begin{tabular}{lcc}
\hline Variable & Coefficient & Standard Error \\
\hline Farmer Location & 0.2768 & 0.3167 \\
Seasonality*Access to any irrigation technology & $0.8389^{* *}$ & 0.3502 \\
Farmer education & $0.0947^{* *}$ & 0.0422 \\
Off farm income source & -0.4680 & 0.3130 \\
Source of Seed & 0.0467 & 0.3109 \\
Farm size for tomato cultivation & 0.1604 & 0.1081 \\
Farmer association & -0.1613 & 0.4200 \\
Access to credit & 0.5303 & 0.5107 \\
Farmer experience*Weighted average price & $0.0021^{* * *}$ & 0.0004 \\
\hline
\end{tabular}

Source: Regression Estimation from Author's Tomato Farmer Survey Data (2011)***p $<0.01$, $* * \mathrm{p}<0.05$ and $* \mathrm{p}<0.10$

\section{Copyrights}

Copyright for this article is retained by the author(s), with first publication rights granted to the journal.

This is an open-access article distributed under the terms and conditions of the Creative Commons Attribution license (http://creativecommons.org/licenses/by/3.0/). 